SECTION 13. Geography. History. Oceanology. Meteorology.

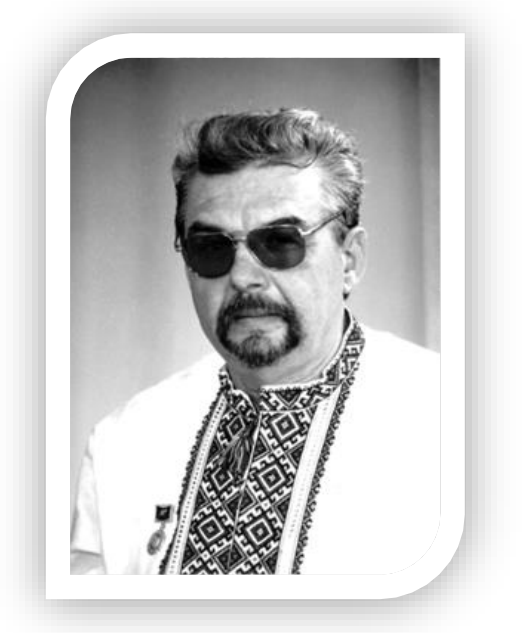

Sergey Iosifovich Tatarinov candidate of historical Sciences, associate Professor, corresponding member of International Academy of

Theoretical \& Applied Sciences, assistant professor of engineering education, Educational and Scientific Professional Pedagogical Institute of Ukrainian Engineering and Pedagogical

Academy

tatbronza@yandex.ua

\title{
BAKHMUT MUNICIPAL DUMA AND PUBLIC LIBRARIE'S DEVELOPMENT
}

Abstract: On the basis of printed materials of Bakhmut Duma, the creation of public libraries in the provincial town, its membership, work plan and financing were analyzed.

Key words: library, the Duma, the Zemstvo, book, newspaper, reader

УДК 94(477):37.014

\section{БАХМУТСКАЯ ГОРОДСКАЯ ДУМА И РАЗВИТИЕ ПУБЛИЧНЫХ БИБЛИОТЕК}

Аннотация: На основе печатных материалов Бахмутской Думы проанализированы создание публичных библиотек в уездном городе, их состав, порядок работы, финансирование.

Ключевые слова: библиотека, Дума, земская управа, книга, газета, читатель.

\section{БАХМУТСЬКА МІСЬКА ДУМА ТА РОЗВИТОК ПУБЛІЧНИХ БІБЛІОТЕК}

Анотація: На підставі вивчення друкованих матеріалів Бахмутської Думи проаналізовано створення публічних бібліотек у повітовому місті, їх склад, порядок роботи, фінансування.

Ключові слова: бібліотека, Дума, земська управа, книга, газета, читач.

Історія бібліотечної справи в Донбасі практично не вивчена, бо перші бібліотеки до 2-ї поливини 19 ст. виникали тільки у повітовому центрі Бахмуті, до початку 20 ст. у інших населених місцях були нечисленними. освіти.

Однак, саме публічні бібліотеки були важливою ланкою позашкільної народної

Важливу роль у створенні мережі бібліотек відігравали земські установи та їх діячі. Білоконський І.П. ставив питання про створення бібліотек-читалень при кожній школі [1]. Вахтеров В.П., відомий методист та оорганізатор педагогічних курсів, наполягав на необхідності створення сільських бібліотек земством давав рекомендації щодо їх діяльності [2]. Григорьев П. наполягав на створенні земствами зразка каталогу 
для своїх бібліотек [3]. Веселовський Б. Б. зібрав та опублікував відомості про кількість земських народних бібліотек по повітам Росії [4, с.239-243].

Дослідження 3 історії бібліотечної справи за часів незалежної України на Донеччині належать тільки автору [ 5, 23-26].

Першою публічною бібліотекою для жителів Бахмуту стала особиста бібліотека викладача Духовного училища Ф.І.Вартмінського. Вартминський Феодосій Іванович був сином протоієрея, працював 4-м вчителем з 14 серпня 1863 р., викладав російську мову, церковний статут та нотні співи. Працював до 3 травня 1869 р. Був священиком Благовіщенської, Троїцької церков Бахмуту, законовчителем нижнього відділення повітового (міністерського) училища. У травні 1869 р. Вартминський перейшов на службу у Слісаветградське духовне училище вчителем Закону Божого [6].

Вартминський мав велику бібліотеку вдома, якою користувалася міська громада. Було навіть видано «Каталог библиотеки госпожи М.А.Вартминской» [6].

Бібліотека була залишена у Бахмуті. У 1869-1870 рр. відома під назвою „городской библиотеки И.А Нилуса".

Новою формою розповсюдження книжок у останній чверті 19 ст. стали лавки 3 читальними кімнатами-бібліотеками.

Книжна лавка бахмутського купця грека Єгора Єрицпохова відкрита за дозволом губернатора у 1883 р., торгувала «преимущественно религиозными книгами и учебниками», мала читальну кімнату [7].

Книжкова лавка з бібліотекою міщанки Ганни Лейбової губернатором дозволена у 1886 р., «мала переважно релігійні книги та підручники» [7].

У Звіті Думи за 1894 р. є «Опис бібліотек і читачів, не рахуючи бібліотек шкільних, на 01.01.1894 рік». В ньому вказані розміри внесків і вартість читання книг і журналів [8].

В 1896-1897 pр. у Бахмуті був відкритий Народний Будинок, де була бібліотека, якою завідувала М.В. Ковтуненко, дочка секретаря Земської управи [9].

Ії̈ сестра Галина вела листування з Л.М.Толстим.

В 1902 році новий Народний Будинок за 30 тисяч рублів було збудовано на Торговій площі: із залом на 500 глядачів, сценою для виступу театральних труп, «чайною тверезості», в 2 кімнатах була бібліотека Лейбової, що налічувала 20 тис. книг, одержувала 9 щомісячних і 8 щотижневих газет і журналів. В бібліотеці в 1902 році було 407 читачів (274 чоловіків і 133 жінок), видано за рік 18721 книг. Наприклад, Майн Ріда прочитали 1278 чоловік, Жюль Верна - 1113, третім за популярністю був М.В. Гоголь. Бібліотека пані Лейбової була платною [10].

Бібліотека-читальня «Товариства народної тверезості» до червня 1912 року одержувала періодичні видання «Нива», «Голос Москви», «Росія», «Російська правда», «Сільський вісник». Газета «Донецьке слово» відзначала, що «в цій бібліотеці багато книг, пошкоджених "читачами-вандалами, такими суб'єктами несуться цілі книги за пазухами, а газети і журнали в кишенях. I все це у присутності сторожів і читаючої публіки... Для боротьби з таким злом книги і журнали тримають під замками, прикріплюють їх ланцюгами до столів і полиць».

В 1899 році Катеринославське губернське земство на честь 100-річчя 3 дня народження О.С. Пушкіна вирішило відкрити в усіх повітових містах бібліотеки для вчителів. Бахмутське земство і жителі міста, бажаючи гідно по шанувати пам'ять геніального поета, вирішили відкрити в місті бібліотеку імені О.С. Пушкіна [10].

Бахмутська Дума на засіданні 22 лютого 1899 року виділила на вшановування пам'яті поета 300 рублів. В цьому році бібліотека прийняла перших відвідувачів і стала називатися «Пушкінською вчительською бібліотекою», призначалася для вчителів земських шкіл повіту [11]. 
«Народна газета Бахмутського земства» в 1909 році відзначала у великій статті «Значення народних читалень» розвиток цього процесу у повіті: «бажано, щоб земство звернуло більш серйозну увагу на склад книг в існуючих бібліотеках і постаралося поповнити тими виданнями, в яких понад за все має потребу наше селянство, мають близьке відношення до народного життя».

В 1911 році на сесії земства завідуючий шкільним відділом Г.О. Філь запропонував перейменувати Пушкінську вчительську бібліотеку в «Бібліотеку службовців повіту» [11].

В 1912 році бібліотека налічувала 828 томів художньої літератури і 1003 томів педагогічних видань, виписувала журнали "Вісник знань", "Нива", додаток до журналу "Нива" і багатотомні видання творів російських письменників-класиків, декілька газет, протягом року "Народну газету Бахмутського земства". Пушкінська бібліотека земських службовців вважалася найкращою в повіті; вона мала значний внесок в культурне життя повіту. Через 12 років після відкриття значна частина книг і журналів стали непридатними для використовування. У зв'язку 3 цим земська Управа розпорядилася списати з бібліотеки 1008 томів і продати на макулатуру. Залишилося в бібліотеці 828 томів, з них 150 томів періодичних видань [12].

Катеринославське губернське земство в 1912 році виділило для Пушкінської бібліотеки 300 рублів. В подальші 3 роки бібліотека значно поповнилася різноманітною літературою.

В 1912 році «залишилися невикористані 100 рублів, відпущені губернським земством».

До 1 січня 1914 року у земській бібліотеці було 19 томів по богослов'ю, 555 - по логіці, педагогіці, філософії, народній освіті, 113 - 3 історії і географії, 88 томів біографій, 58 - по економіці, юриспруденції, 169 - по природознавству, 1295 найменувань художньої літератури, 164 - по історії, літературі і критиці, 71 довідник, 102 підручники народних училищ, 16 книг з історії мистецтва і 117 книг для дітей. В земській бібліотеці до початку Першої світової війни налічувалося 3494 томи 11.

В 1913-1914 pр. Пушкінську бібліотеку службовців земства відвідувало 270 читачів [13].

В 1909 році по всій Росії урочисто відзначали 100-річчя з дня народження М.В. Гоголя [14].

В «Народній газеті Бахмутського земства» була розміщена біографія М.В. Гоголя і матеріали про письменника - «Гоголь - це письменник наших думок i почуттів».

20 лютого 1909 р. відбулося засідання Думи з святкування ювілею М.В. Гоголя відзначивши, що «Гоголь мав і довго матиме широке суспільне значення, Управа вважала, що «пам'ять геніального письменника повинна бути відзначена в такій формі, яка носила б в собі виховно-просвітницьку ідею, мала б суспільний характер, стала надбанням всіх верств населення i завжди б нагадувала про велику людину...пам'ятником М.В. Гоголю була б бібліотека, в якій так має потребу 24тисячне населення Бахмуту і відсутність якої - прогалина в духовному житті городян» [15].

Бахмутська Дума 20 лютого 1909 р. одноголосно ухвалила «на честь 100-річчя 3 дня народження М.В. Гоголя відкрити на доходи міста бібліотеку з безкоштовним кабінетом для читання, присвоїти їй назву «Бахмутська міська ім. М.В. Гоголя бібліотека», для фінансування ії позичити з місцевого запасного капіталу 3000 рублів; доручити Управі розробити Статут бібліотеки і умови роботи абонементу», « бібліотека відкриє свої двері перед читаючим міським населенням в травні або в червні 1909 р.» [16]. 
В червні 1909 р. бахмутська публічна бібліотека ім. М.В. Гоголя почала обслуговувати читачів.

За діяльністю i утриманням бібліотеки стежив спеціальний Бібліотечний комітет, Головою якого обрали в.о. голови Думи лікаря М. І. Новгородцева.

Читання книг і журналів у бібліотеці було платним: за читання книг по I розділу - за читання 4-х книг - 8 рублів на рік. Велику допомогу бібліотеці надало земство [17].

17 січня 1911 року Катеринославський губернатор не затвердив головою Комітету Гоголівської бібліотеки М.I. Новгородцева, тому Дума вибрала В.В. Шабашева, якого 18 лютого губернатор затвердив. До складу Комітету бібліотеки входили за посадою міський Голова, директори учбових закладів, інспектори народних училищ.

Педагогами 11 жовтня 1912 року було піднято «питання про дозвіл учням читати в Гоголівській бібліотеці під спостереженням їх начальників».

В 1912 році в Гоголівській бібліотеці виписували періодичні видання «Російське слово», «Новий час», «Тиждень», «Південний край», «Вісник Європи», «Російська думка», «Сучасний мир», «Російське багатство», «Вісник знань», «Природа і люди». Земство виділило «замість потрібних 300 рублів - 100 рублів».

27 листопаду 1913 року для Гоголівської бібліотеки в друкарні Дерковського був виданий каталог книг вартістю в 350 рублів. Виник конфлікт між головою ревізійної комісії Д. Д. Ревякіним і головою бібліотечного Комітету В.В. Шабашевим через несанкціоновані Думою витрати [18].

В 1914 році до складу бібліотечної Комісії входили: голова - дійсний статський радник В.В. Шабашев, Ф.С. Срицпохов (секретар Управи повіту, редактор «Народної газети»), М.Ф. Вараксін (власник чавуноливарного заводу), Г.С. Лобасов (купець 1-ї гільдії і меценат), кандидатами С.Ж. Штукарев (купець), П.Є. Петрушевский (доглядач Тюремного Замку), Д.Д. Ревякін (купець), В.В. Ліпчай (урядовець та гласний Думи) [19].

Восени 1915 року в Думі відбулися вибори голови і членів опікунської Ради Гоголівської бібліотеки.

«Народна газета Бахмутського земства» відзначала, що «Пушкінська бібліотека закрита для широкої публіки, міська Гоголівська абсолютно незадовільна, а інших бібліотек громадського користування в місті немає».

Міська Дума відгукувалася на знаменні дати в історії російської літератури. В жовтні 1910 року Дума «в ознаменування 100-річчя з дня народження великого критика Белінського» заснувала стипендію його імені для учнів реального училища і придбала портрет поета в міську бібліотеку.

В зв'язку з 100-річчям $з$ дня народження М.Ю. Лермонтова Дума в жовтні 1914 року вирішила помістити портрет поета в міській бібліотеці, відслужити панахиди в міських школах, звільнити учнів від занять, «влаштувати читання пам'яті поета i роздати учням брошури про М.Ю. Лермонтова» [19].

В грудні 1915 року в газеті «Бахмутське життя» В. Демянов писав, що «населення, службовці і робітники не мають нагоди нею користуватися.., вона у всі свята абсолютно закрита.., під свята закривається о 2 годині дня. Сдиний день під свята, коли робота кінчається на заводах в 5 годин вечора і робочі мають нагоду запастися книжкою для святкового читання безкоштовно, почитати цікаву газету». В.Демянов пропонував в свята відкривати бібліотеку з 11.00 до 14.00 і перед святами відкривати в 7 годин вечора.

Книгами бібліотеки користувалися не тільки городяни, але і арештанти. Восени 1913 року доглядач Арештного Дому П.Є. Петрушевський звернувся в Думу і Управу про відпуск книг для ув'язнених на суму 200 рублів. 
В газеті «Бахмутська копійка» в 1914 році поміщена замітка про те, що «нерідко узяті 3 бібліотек книги повертаються читачами в спотвореному вигляді, вирвані сторінки, зроблені помарки і відмітки, з книг деяких авторів вирвані найцікавіші місця собі «на пам'ять».

Земство повіту в 1912-1915 рр. виділяло на розвиток бібліотечної справи 2300 рублів [19;20].

В січні 1915 р. в газеті «Бахмутське життя» було опубліковано звернення - «Нас просять звернути увагу на відсутність в бібліотеці імені Гоголя карти військових дій, що представляє велику незручність для читачів, змушених вдаватися до допомоги енциклопедичного словника».

Існували у Бахмуті «професійні» бібліотеки. На бібліотеку Комерційного Клубу асигнували у 1912 p. 300 рублів на рік, але бібліотекар не зумів їх витратити і залишив майже 250 рублів, бібліотека « залишається в хаотичному безладному стані» [21].

На зборах Товариства прикажчиків та їх помічників відзначалося, що Товариство мало бібліотеку-читальню, де книги за плату брали городяни, але Статут це обмежив тільки членами Товариства, не стало коштів на нові книги у 1912 р. [22].

\section{References:}

1. Belokonskiy I. P. Nasuschnyiy vopros $\mathrm{v}$ oblasti narodnogo obrazovaniya / I. Belokonskiy // Rus. shkola. - 1900. — \# 2. - S. 138-151.

2. Vahterov V. P. Selskie biblioteki. V.P.Vahterov // Sev. vestn. - 1894.—\# 5.—S.1— 19

3. Grigorev P.O. Znachenie mestnogo printsipa pri komplektovanii bibliotek knigami : (prisposoblenie rek. kataloga k usloviyam dannoy gubernii)/ P.O.Grigorev // Vestn. nar. obrazovaniya. - 1916. -\# 2.-S. 243-244.

4. Veselovskiy B. B. Kalendar-spravochnik zemskogo deyatelya na 1915 god / sost. B. B. Veselovskiy. -Pg. : Zhurn. «Zem. delo» i «Gor. delo», [1914]. - XII, - 418 s..

5. Tatarinov S.Y.Viniknennya bIblIotek u DonbasI u 18-19 stolIttyah /S.Y.Tatarinov//Suchasna nauka:teorIya I praktika. ZbIrnik materIalIv 4-Yi VseukraYinskoYi naukovo-praktichnoYi zaochnoYi konferentsIYi 27-28 chervnya 2013 r. -KiYiv, 2013, - s.6871.

6. Butovskiy A.I. Istoricheskaya zapiska o Bahmutskomduhovnom uchilische za 60 let./A.I.Butovskiy// - Bahmut, 1893.

7. RGIA. - F. 776 op. 20 d. 1139 1.138-140ob. Delo po dostavleniyu gubernatorami vedomostey o suschestvuyuschih zavedeniyah pechati i o knizhnoy torgovle. 19.09.189031.12.1890

8. Otchet gorodskoy upravyi za 1894 g. -1895 . -119 s.

9. Otchet Bahmutskoy gorodskoy upravyi za 1897 g. -Bahmut, 1898. - $127 \mathrm{~s}$.

10. Zhurnalyi XXXVI ocherednogo Bahmutskogo uezdnogo zemskogo sobraniya. Bahmut, 1902. - $267 \mathrm{~s}$.

11. Zhurnalyi XXXIII ocherednogo sobraniya. -Bahmut, 1899. - $423 \mathrm{~s}$.

12. Otchet bahmutskoy gorodskoy upravyi za 1899 g. -Bahmut,1900. -129 s.

13. Otchet ob ispolnenii Bahmutskoy uezdnoy zemskoy upravoy postanovleniy zemskogo sobraniya 1910 goda: 1) Cherezvyichaynogo 22-23 fevralya, 2) 27 aprelya, 3) 7-go sentyabrya i 4) ocherednogo s 28 sentyabrya po 5-e oktyabrya vklyuchitelno. - Bahmut, 1911. $-114 \mathrm{~s}$

14. Zhurnalyi Bahmutskogo uezdnogo zemskogo sobraniya 1913 goda. -Bahmut : Tip. Valdshteyna, - 1913;Otchet Bahmutskoy uezdnoy zemskoy upravyi za 1913 god. - Bahmut : Tip. Valdshteyna, -1914 
15. Zhurnalyi 49 zasedaniya Bahmutskoy uezdnoy hzemskoy upravyi 20-26 oktyabrya. - Bahmut, -1914; Otchet Bahmutskoy uezdnoy zemskoy upravyi za 1914 g. Bahmut : Tip. Valdshteyna, - 1915

16. Sistematicheskiy svod postanovleniy Ekaterinoslavskogo gubernskogo zem $\neg$ skogo sobraniya -Ch. II (1890 -1913 gg.). -Ekaterinoslav, 1916.

17. Otchet gorodskoy upravyi za 1910 god. -Bahmut, 1911. - 105 s.; Otchet gorodskoy upravyi za 1913 god. -Bahmut, 1914. - $123 \mathrm{s.}$

18. Otchet Bahmutskoy uezdnoy zemskoy upravyi za 1913 g. - Bahmut, 1913.-33s.

19. Otchet Bahmutskoy uezdnoy zemskoy upravyi za 1914 g. - Bahmut, 1914.-40s.

20. Zhurnal chrezvyichaynogo sobraniya Bahmutskoy uezdnoy upravyi 31 marta 1915 g. - Bahmut : Tip. Valdshteyna, 1915, - 234 s.

21. Bahmutskiy listok, 22 aprelya 1912

22. Bahmutskiy listok, 23 aprelya 1912

23. Tatarinov S.I.Rol bibliotek $\mathrm{v}$ razvitii narodnogo obrazovaniya $\mathrm{v}$ Bahmutskom uezde v 19- nachale 20 st. /S.I.Tatarinov //Suchasna nauka:teorIya I praktika. ZbIrnik materIalIv 4-Yi VseukraYinskoYi naukovo-praktichnoYi zaochnoYi konferentsIYi 27-28 chervnya 2013 r. -KiYiv, 2013, - s.71-74;

24. Tatarinov S.I. Rol organov samoupravleniya $v$ razvitii bibliotek v Bahmutskom uezde kak istochnika narodnogo prosvescheniya v 19-nachale $20 \mathrm{st}$. /S.Y.Tatarinov//Pitannya suchasnoYi osvIti ta nauki.MaterIali 9-Yi MIzhnarodnoYi naukovo-praktichnoYi InternetkonferentsIYi, 18-20 lipnya 2013 r.. -K., -2013, -s.38-43;

25. Tatarinov S.I.Rol bibliotek $\mathrm{v}$ razvitii narodnogo obrazovaniya $\mathrm{v}$ Bahmutskom uezde v 19-nachale 20 st./S.I.Tatarinov //Dosyagnennya sotsIalno-gumanItarnih nauk v suchasnIy UkraYinI. MeterIali 3-Yi VseukraYinskoYi naukovoYi konferentsIYi z mIzhnarodnoyu uchastyu. Ch.2, -SImferopol, 26 kvItnya 2013, -s. 184-187;

26. Tatarinov S.Y.Viniknennya bIbllotek u DonbasI u 18-19 st. /S.Y.Tatarinov //Dosyagnennya sotsIalno-gumanItarnih nauk $\mathrm{v}$ suchasnIy UkraYinI. MeterIali 3-Yi VseukraYinskoYi naukovoYi konferentsIYi z mIzhnarodnoyu uchastyu. Ch.2, -SImferopol, 26 kvItnya 2013, - s.189-192 